\title{
高分子の自己組織化を利用する半導体微細加工技術と 材料開発への展望
}

\author{
Prospect for Semiconductor Microfabrication Technology and Materials \\ Development Utilizing Polymer Self-Assembly
}

材料技術委員会

\section{1. はじめに 次世代の半導体微細加工技術}

スマートフォンやタブレット PC, 自動車, 薄型テレビな どを支えるエレクトロニクス技術の進展が目覚ましい。半 導体の微細加工技術を駆使した集積回路パターンの縮小に よる高性能化と低コスト化が原動力の源である。

半導体回路はフォトリソグラフィ技術, すなわち原版と なるマスクパターンを用いレジストが塗布された半導体基 板上に縮小露光することにより製造される。回路パターン の微細化には, 露光光の短波長化と露光波長に適切なレジ スト開発が重要となる。現在, 実用化されている光源の波 長は $\operatorname{ArF}$ (フッ化アルゴン) エキシマレーザによる $193 \mathrm{~nm}$ である。さらなる微細化のために, 現像後のレジストパ ターンの両側の側壁を使い, パターンピッチを $1 / 2$ サイズ に縮小するダブルパターニングや露光に軟 X 線領域の極端 紫外光 (EUV: Extreme Ultraviolet)を用いる新しい微細加工 技術への取り組みが積極的に行われている ${ }^{1)}$ 。EUVリソグ ラフィは ArF エキシマレーザに対し露光波長が $1 / 10$ 以下 となる波長 $13.5 \mathrm{~nm}$ を用いることから, パターン幅が $10 \mathrm{~nm}$ を下回る高い解像力に大きな期待が寄せられている。しか しながら, 一方で EUV 露光装置には高出力の露光を安定 供給する技術や高コストの課題が残されている。

このような背景の下, 高分子の自己組織化現象と誘導自 己組織化 (Directed Self-Assembly, DSA) 技術を活用するボト ムアップ型リソグラフィ技術, “ブロック共重合体リソグラ フィ（BCPリソグラフィ）”に対する関心が高まってい

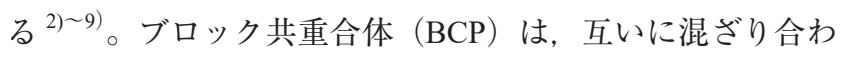
ない 2 種以上の異なる高分子鎖が末端で化学的に結合した ポリマーであり, 同種ポリマー間の引力と異種ポリマー間 の斥力によってミクロ相分離を起こす。BCP リソグラフィ はこの BCP のミクロ相分離によって形成される数〜数十 $\mathrm{nm}$ サイズの球状, シリンダー状, あるいはラメラ状のミク ロ相分離ドメインを基板上の薄膜として秩序的に配列し, 微細加工を行う技術である。 BCP リソグラフィによるパ ターン幅はミクロ相分離ドメインの恒等周期長と密接に関 係している。また，パターンの形状はミクロ相分離ドメイ
ンの形態と基板面に対する配向方向によって決定づけられ る。すなわち, BCP の薄膜における高次構造が果たす役割 は大きく, 材料の要求特性に応じた BCP の分子構造設計と ミクロ相分離ドメインの配列と配向制御の最適化が重要と なる。本稿では, 高分子の自己組織化を駆動力とする次世

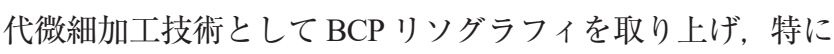
近年関心の高いミクロ相分離ドメインの垂直配向制御につ いて筆者らの研究例を含めた最新状況を述べる。

\section{Directed Self-Assembly (DSA) 誘導自己組織化技術 ${ }^{2}$}

BCP による自己組織化現象をパターニングに活用すると きの最大の課題は, 所望の形状からなるナノ構造を任意の 場所に欠陥なく形成することにある。DSA はその自己組織 化過程をガイドパターンと呼ばれる人工的な構造物によっ て制御し，ミクロ相分離ドメインの形成を誘導する技術で ある。ガイドパターンは従来のフォトリソグラフィ技術に よって作製することができる。主には，従来のリソグラ フィ技術により形成した凹凸パターンの物理的構造と側面 と底面からの化学的相互作用によって自己組織化を誘起す る Graphoepitaxy 法と凹凸構造をもたないイメージングレイ ヤー (Imaging Layer) のパターン化改質表面の化学的相互作 用によって自己組織化を誘起する Chemoepitaxy 法に大別さ れる（図 1）。これらを利用した代表的な BCP のパターニ ングとして, コンタクトホール径の縮小とライン＆スペー スパターンの縮小への適用が考えられている。

\section{1 コンタクトホール}

コンタクトホールは半導体デバイスの中でトランジスター 素子と配線層の接続に使われる代表的な回路である。その 径をより小さくすることが求められる中, Graphoepitaxy 技 術を用いた口径の縮小が試みられている。先ず，フォトリ ソグラフィ技術によってレジスト層に作製した大きな口径 の孔をガイドホールとして用い，そこにBCPを流し达み自 己組織化させる。ガイドホールの中でミクロ相分離ドメイ ンが形成された後, 中心部のドメインのみを選択的エッチ ングにより取り除くことで，新たにより微細な口径からな る孔を作り出すことができる。DSAに最もよく使われる 
Directed Self-Assembly : DSA

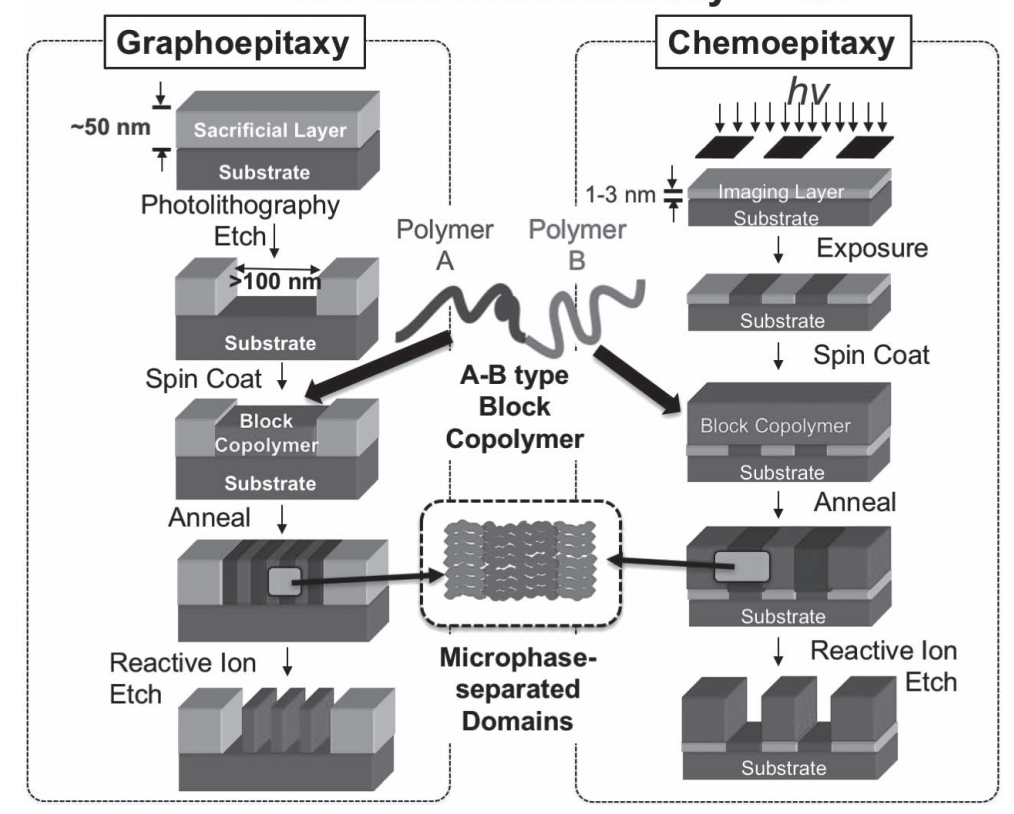

図 1. 誘導自己組織化技術 (DSA) の概略図

BCP として, ポリスチレン (PS) とポリメタクリル酸メチル (PMMA) からなる BCP (PS- $b$-PMMA) を例にあげる。フォ トリソグラフィによるガイドホールの加工において, 最終 的にドライエッチングにより処理されたホール内壁は PMMA に対しより高い親和性が示される。そのため, PS- $b$ PMMA をガイドホール内で自己組織化させるとガイドホー ルの内壁はごく薄い PMMA 層で覆われる。しかしながら, その層は明確には構造観察ができないほどにきわめて薄い ため, ホール内の中心にPMMAのシリンダー, その外側 をPS 層が覆った構造が形成される。得られたPMMAのシ リンダーを選択的に除去するとガイドホールの中心に直径 の小さな孔を作り出すことができ, コンタクトホール径の 縮小を可能にする。一方で, 本プロセスには課題も残され ている。ガイドホール内に形成されるシリンダー状のミク ロ相分離ドメインが底部まで完全に到達せずに, 孔が貫通 しない場合がある。現在, シリンダー除去のエッチング条 件の検討や底部と BCP の親和性を考慮に入れた自己組織化 などの対応策が試されている。

\section{2 ライン\&スペースパターン}

ライン\&スペースは回路配線の基本となるパターンであ る。近年では, ライン\&スペースパターンで構成された三 次元構造からなる FinFET トランジスタが提唱されたこと もあり, その微細化の要求に対応可能な技術としてDSAに 注目が集まっている。DSA 技術によるBCP のライン＆ス ペースパターンの形成には, 主に Chemoepitaxy 技術が適用 される。フォトリソグラフィ技術によって作製したピッチ 長の広い直線状のパターンを BCP の Chemoepitaxy 技術に より縮小パターンに変換することができる。例えば, フォ トリソグラフィ技術でパターン化できるピッチ長からな
り, 且つ PS と PMMA に対しそのパターン表面の濡れ性が 異なる基板を準備する。そこに $\mathrm{BCP}$ の薄膜を作製し自己組 織化を促進させると, PS と PMMA はガイドパターンの表 面の濡れ性に応じて自己集合し，最終的にミクロ相分離ド メインの配列パターンが得られる。ガイドパターンのピッ チ長とミクロ相分離ドメインの恒等周期長は密接に関係し ている。BCPの分子量の精密制御, およびガイドパターン のピッチ長の調整によるパターンの補間技術を利用するこ とにより簡便にパターンの縮小を達成することができる。

\section{BCP ミクロ相分離ドメインの微細化と垂直配向化 技術}

DSA 技術の進展によって, BCP のミクロ相分離ドメイン の配列制御技術は確立されつつある。その一方で, 半導体 基板への構造転写を高精度に行うためには, ミクロ相分離 ドメインの配列だけではなく配向制御も重要となる。さら に, BCP リソグラフィの最大の特徴はパターン幅 $10 \mathrm{~nm}$ を 下回る “sub-10 nm”の微細加工の実現にある。そのために は, BCP の中でも high- $\chi \mathrm{BCP}$ と呼ばれる材料を用いた上 で, ミクロ相分離ドメインの垂直配向を達成することが求 められる。 high- $\chi \mathrm{BCP}$ とは, 一般に Flory-Huggins 理論にお ける相互作用パラメータ $\chi$ が比較的高い值を示す BCP のこ とを指す ${ }^{10)}$ 。ミクロ相分離ドメインの大きさと間隔は $\mathrm{BCP}$ の分子量と密接に関係している。すなわち, 単純にはより 低分子量体の high- $\chi \mathrm{BCP}$ を用いることでドメインの微細化 を推し進めることができる。しかしその一方で, high- $\chi \mathrm{BCP}$ の多くは極性の大きく異なるポリマーによって構成される ことから, 一般には, どちらか片方のポリマーが膜表面, あるいは基板表面に偏析し, それらの界面を選択的に覆っ 
(A) Solvent Anneal Method

(B) Top-Coat Method

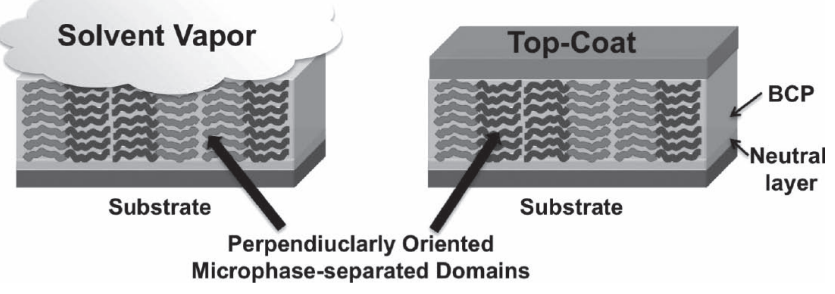

図 2. 薄膜におけるミクロ相分離ドメインの垂直配向化技術

(A) 溶媒アニール法，(B) トップコート法

た膜が得られる。これは，ミクロ相分離ドメインが膜面に 平行に配向した構造となり本技術の目的には不向きとなる。

これらの課題を解決する方法として, 基板の表面改質に 実績が残されている。BCP の構成ポリマーが, 各々にほぼ 等しい親和性を示す中性化膜と呼ばれる改質剤が用いられ る。例えば, PS-b-PMMA の薄膜において, PS と PMMAの 組成比が適切に調整されたランダム共重合体 (PS-ranPMMA)を表面にグラフトした基板が用いられ，ミクロ相 分離ドメインの垂直配向が制御される。ただし, PS- $b$ PMMA の場合には, PS と PMMA の表面張力がほぼ同等で あることもミクロ相分離ドメインの垂直配向に強く関わっ て扮り，基板界面のみならず薄膜表面からもドメインの配 向が起こる。一方で, high- $\chi \mathrm{BCP}$ の場合は簡単ではない。 中性化膜によって基板面の垂直配向を制御することができ たとしても, 空気界面側は偏析が起こり平行配向構造が形 成される。そこで, 空気界面の中性化を図る手法として溶 媒アニーリング法やトップコート法が考案され, ミクロ相 分離ドメインの垂直配向の事例が報告されている（図 2)。

\section{1 溶媒アニール法}

溶媒アニール法は, $\mathrm{BCP}$ 薄膜を溶媒蒸気下に曝露するこ とにより溶媒分子を $\mathrm{BCP}$ 中に取り込ませて自己組織化を誘

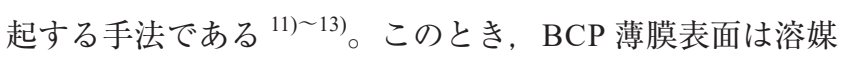
分子の蒸気と接する環境下に置かれる。そこで high- $\chi \mathrm{BCP}$ を構成する各ポリマーの親和性がほほ等しくなる溶媒を適 切に選択することにより, BCP 薄膜界面に打いて中性化条

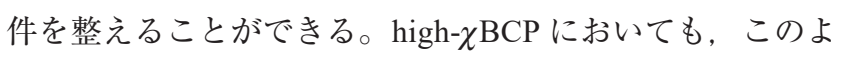
うな環境を整えることによりミクロ相分離ドメインの垂直 配向が達成される。Ross らは ${ }^{12)}$, PS とポリジメチルシロ キサン (PDMS) で構成された high- $\chi$ BCP (PS- $b$-PDMS) の溶 媒アニールを試み, シリンダーとラメラドメインの垂直配 向に成功したことを報告している。しかしながら，その報 告の中で溶媒アニールによって PS- $b$-PDMS の垂直配向がほ ほ達成される一方で, その最表層では平行シリンダードメ インが僅かに形成されることも示されている。そこで, 最 表層のドメインをドライエッチングにより取り除いた後 に, 垂直配向構造を得ている。溶媒アニール法は実験が簡 単である一方で, 溶媒種類の探索やアニール時間, BCP の 組成比に応じた最適化は決して容易でない場合がある。

\section{2 トップコート法}

Willson らは high- $\chi \mathrm{BCP}$ の垂直配向を達成するために，基 板界面側だけでなく薄膜表面にも中性化膜を置くトップ コート法を開発し報告している ${ }^{14)}$ 。トップコート膜を構成 するポリマーには, 無水マレイン酸とその他ノルボルネン あるいはその誘導体とスチレン誘導体などを組み合わせた 三成分からなるランダム共重合体が用いられている。この ランダム共重合体は無水マレイン酸の効果により BCP 薄膜 を溶かさない塩基性水溶液で塗布できるように工夫されて いる。ノルボルネンやスチレン誘導体は膜の熱安定性や極 性の調整のために導入されている。このランダム共重合体 を $\mathrm{BCP}$ 薄膜上にスピンコートし熱处理を加えるとマレイン 酸の脱水による閉環が起こる。これにより無水物による極 性の再形成と切替えが起こり, 中性化膜として機能する。 熱処理のみでは垂直配向が起こらないケイ素含有ポリスチ レン誘導体からなる BCP が, トップコート後の熱処理では 線幅 $9 \mathrm{~nm}$ で垂直配向パターンが形成されることが報告さ れている。この技術は, 多様な high- $\chi \mathrm{BCP}$ の垂直配向に適 用範囲が広がっており，信頼ある手法のひとつとして注目

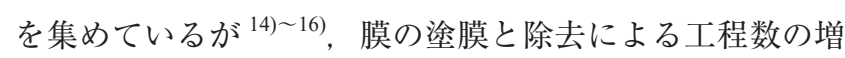
加がプロセス上の課題として残されている。

\subsection{BCP の分子構造設計による垂直配向制御法}

筆者らは, 溶媒アニール法やトップコート法に代わり， high- $\chi \mathrm{BCP}$ に対する分子構造設計によるミクロ相分離ドメ インの垂直配向制御を報告している。溶媒アニール法掞よ びトップコート法もミクロ相分離ドメインの垂直配向には 優れた実績があり有効な手法である。しかしながら，究極 にはこれらの手法を用いることなく， BCP そのものを熱処 理などによって簡便に垂直配向できることが望ましい。

これまで筆者らは, high- $\chi \mathrm{BCP}$ 材料開発研究の一環とし て, かご形シルセスキオキサン (POSS) 含有ポリメタクリ レート系 BCP（ポリメチルメタクリレートーb-ポリ（POSS メタクリレート), PMMA-b-PMAPOSS）について検討を重

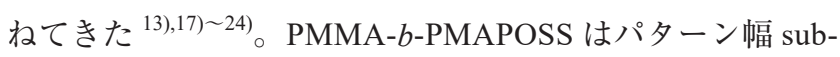
$10 \mathrm{~nm}$ の形成が容易に可能である一方で, 他の多くの high- $\chi$ BCP と同様にドメインの垂直配向は困難であった。 これは, 後の実験にて BCP の構成成分である PMMA と PMAPOSS の表面張力の大きな差が原因であることがわ かった。そこで PMMA $\left(47.2 \mathrm{~mJ} \mathrm{~m}^{-2}\right)$ に代えて PMAPOSS $\left(28.7 \mathrm{~mJ} \mathrm{~m}^{-2}\right)$ と同程度の表面張力を示すトリフルオロエチ ル基を有するフッ素含有ポリメタクリレート ${ }^{24)}$ (PTFEMA, $25.1 \mathrm{~mJ} \mathrm{~m}^{-2}$ )を取り上げ，新たにBCP (PMAPOSS- $b$ PTFEMA $)^{25}$ の合成を行い薄膜における垂直配向について検 討した（表面張力はいずれも研究室における同条件測定下 における実験値)。PMAPOSS- $b$-PTFEMA の溶液からシリコ ン基板上にスピンキャスト膜を作製し，大気下， $150^{\circ} \mathrm{C} に$ て3 分間の熱处理を行ったところ, 興味媣いことにミクロ 相分離ドメインが基板面に垂直に配向した膜が得られた。 


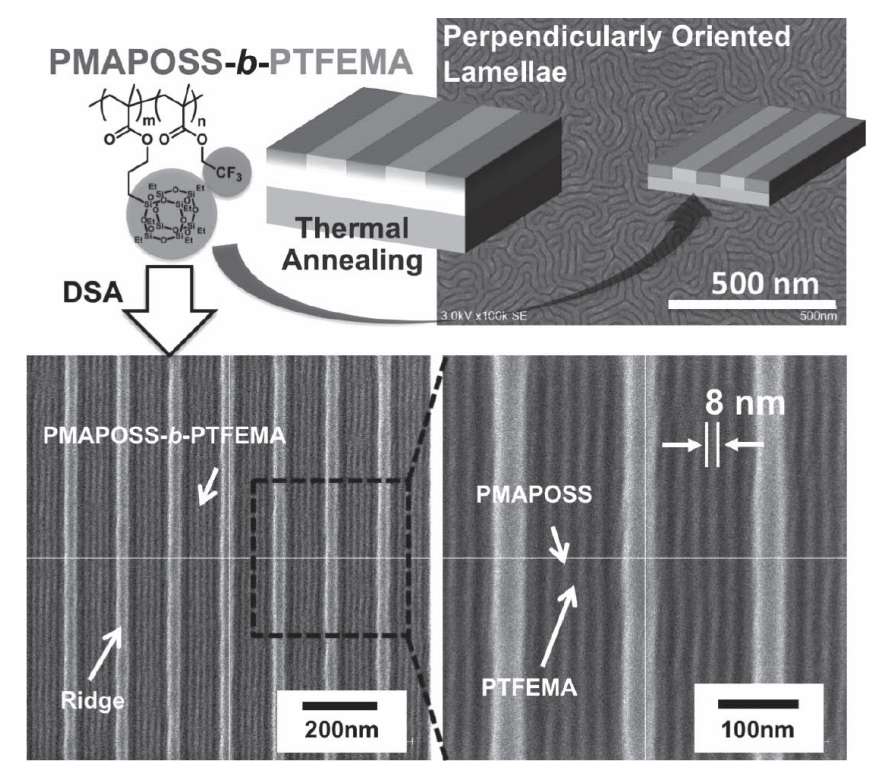

図 3. high- $\chi B C P$ の垂直配向と誘導自己組織化 (DSA) によ る配列制御
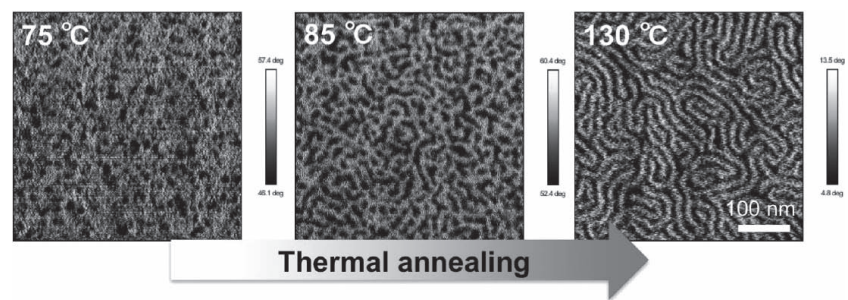

図 4. 熱処理におけるミクロ相分離ドメインの垂直配向過程

酸素プラズマエッチング後のパターン幅は $10 \mathrm{~nm}$ を下回っ ていた（図 3)。熱処理前後における薄膜ミクロ相分離ドメ インの構造変化を高速スキャン AFM を用いて調べたとこ ろ, 加熱温度が $75^{\circ} \mathrm{C}$ 付近までは部分的に点状の構造が見 受けられたのに対し, 温度が徐々に上昇するに連れて点状 のドメインが連結し始め, 短い線状のドメインが形成され ていくことが明らかになった（図 4)。これは，加熱により $\mathrm{BCP}$ の拡散とミクロ相分離が促進されたのと同時に, 同程 度の表面張力を示す PMAPOSS と PTFEMA の膜表面への濃 縮が起こり始めたことが起点となっている。この BCP の画 期的な点はこれまで必須であった基板上の中性化膜を必要 としないこと, さらには, 大気下で短時間の熱処理を行う だけで確実にミクロ相分離ドメインの垂直配向膜が得られ ることにある。BCP リソグラフィ開発において, 材料面か ら将来性に富んだ垂直配向制御を示すことができた ${ }^{25), 26) 。 ~}$

\section{4. おわりに}

次世代微細加工の候補技術として, BCP リソグラフィと それに関するミクロ相分離ドメインの垂直配向制御につい て紹介した。半導体回路の製造に対応するためには, 今 後, 数多くの課題を克服しなければならない。その中で
も，高解像度で構造欠陥のないパターン形成技術の開発が 鍵を握ると考えられる。 BCP の自己組織化技術を成熟させ るためには, DSA 技術における欠陥形成のメカニズム解析 や BCP の配向配列制御に関わる周辺材料の精度をさらに向 上させる必要がある。これらを追求し，信頼のある技術に 育て上げることにより, 高性能, 高品質の半導体デバイス を低価格で市場に供給することができる。これらの研究と 技術の早期実用化を実現することで, 社会の発展と向上に 貢献していきたいと考えている。

\section{文責・早川晃鏡 $/$ 東京工業大学}

(2016.12.9- 受理)

\section{文献}

1) 姜 帥現, 井上壮一：“半導体デバイスの微細化を実現する EUV リソグラフィ技術,”東芝レビュー, Vol. 67, No. 4, pp. 36-40, 2012

2) 吉田博史：“高分子の誘導自己組織化で半導体回路を描く, ” 高分子, Vol. 64, pp. 57-62, 2015

3) I. W. Hamley: "Developments in Block Copolymer Science and Technology,” ed. I. W. Hamley, Jhon Wiley \& Sons, p. 1, 2004

4) M. Park, C. Harrison, P. M. Chaikin, R. A. Register, and D. H. Adamson: "Block Copolymer Lithography: Periodic Arrays of $\sim 10^{11}$ Holes in 1 Square Centimeter," Science, Vol. 276, pp. 1401-1404, 1997

5) R. A. Segalman, H. Yokoyama, and E. J. Kramer: "Graphoepitaxy of Spherical Domain Block Copolymer Films," Adv. Mater., Vol. 13, pp. 1152-1155, 2001

6) S. O. Kim, H. H. Solak, M. P. Stoykovich, N. J. Ferrier, J. J. de Pablo, and P. F. Nealey: "Epitaxial self-assembly of block copolymers on lithographically defined nanopatterned substrates," Nature, Vol. 424, pp. 411-414, 2003

7) R. Ruiz, H. Kang, F. A. Detcheverry, E. Dobisz, D. S. Kercher, T. R. Alberecht, J. J. de Pablo, and P. F. Nealey: "Density Multiplication and Improved Lithography by Directed Block Copolymer Assembly," Science, Vol. 321, pp. 936-939, 2008

8) I. Bita, J. K. W. Yang, Y. S. Jung, C. A. Ross, E. L. Thomas, and K. K. Berggren: "Graphoepitaxy of Self-Assembled Block Copolymers on Two-Dimensional Periodic Patterned Templates," Science, Vol. 321, pp. 939-943, 2008

9) S. Jeong, J. Y. Kim, B. H. Kim, H.-S. Moon, and S. O. Kim: "Directed self-assembly of block copolymers for next generation nanolithography," Material Today, Vol. 16, pp. 468-476, 2013

10) S. Minegashi, T. Naruoka, and T. Nagai: "Directed Self Assembly Materials for Semiconductor Lithography,” J. Photopolym. Sci. Tech., Vol. 26, pp. 793-800, 2013

11) S. H. Kim, M. J. Misner, T. Xu, M. Kimura, and T. P. Russell: "Highly Oriented and Ordered Arrays from Block Copolymers via Solvent Evaporation,” Adv. Mater., Vol. 16, No. 3, pp. 226-231, 
2004

12) J. G. Son, K. W. Gotrik, and C. A. Ross: "High-Aspect-Ratio Perpendicular Orientation of PS- $b$-PDMS Thin Films under Solvent Annealing," ACS MacroLett., Vol. 1, pp. 1279-1284, 2012

13) Y. Tada, H. Yoshida, Y. Ishida, T. Hirai, J. K. Bosworth, E. Dobisz, R. Ruiz, M. Takenaka, T. Hayakawa, and H. Hasegawa: "Directed Self-Assembly of POSS Containing Block Copolymer on Lithographically Defined Chemical Template with Morphology Control by Solvent Vapor," Macromolecules, Vol. 45, pp. $292-$ 304, 2012

14) C. Bates, T. Seshimo, M. J. Maher, W. J. Durand, J. D. Cushen, L. M. Dean, G. Blachut, C. J. Ellison, and C. G. Willson: "Polarity-Switching Top Coats Enable Orientation of Sub-10-nm Block Copolymer Domains," Science, Vol. 338, pp. 775-779, 2012

15) H. Yoshida, H. S. Suh, A. Ramirez-Herunandez, J. I. Lee, K. Aida, L. Wan, Y. Ishida, Y. Tada, R. Ruiz, J. de Pablo, and P. F. Nealey: "Topcoat Approaches for Directed Self-Assembly of Strongly Segregating Block Copolymer Thin Films," J. Photopolym. Sci. Tech., Vol. 26, pp. 55-58, 2013

16) A. Ramírez-Hernandez, H. S. Suh, P. F. Nealey, and J. J. de Pabro: "Control of Directed Self-Assembly in Block Polymers by Polymeric Topcoats," Macromolecules, Vol. 47, pp. 3520-3527, 2014

17) T. Hirai, M. Leolukman, T. Hayakawa, M-a Kakimoto, and P Gopalan: "Hierarchical Nanostructures of Organosilicate Nanosheets within Self-Organized Block Copolymer Films," Macromolecules, Vol. 41, No. 13, pp. 4558-4560, 2008.

18) T. Hirai, M. Leolukman, C. C. Liu, E. Han, Y. J. Kim, Y. Ishida, T. Hayakawa, M-a Kakimoto, P. F. Nealey, and P. Gopalan, et al.: "One-Step Direct-Patterning Template Utilizing Self-Assembly of POSS-Containing Block Copolymers," Adv. Mater., Vol. 21, pp. 4334-4338, 2009

19) T. Hirai, M. Leolukman, S. Jin, R. Goseki, Y. Ishida, M-a Kakimoto, T. Hayakawa, M. Ree, and P. Gopalan: "Hierarchical Self-Assembled Structures from POSS-Containing Block Copolymers Synthesized by Living Anionic Polymerization," Macromolecules, Vol. 41, No. 13, pp. 8835-8843, 2009

20) B. Ahn, T. Hirai, S. Jin, Y. Rho, K.-W. Kim, M-a Kakimoto, P.
Gopalan, T. Hayakawa, and M. Ree: "Hierarchical Structure in Nanoscale Thin Films of a Poly(styrene- $b$ - methacrylate grafted with POSS) ( $\mathrm{PS}_{214}-b$-PMAPOSS $\left.{ }_{27}\right)$," Macromolecules, Vol. 43 , No. 24, pp. $10568-10581,2010$

21) H. Yoshida, Y. Tada, Y. Ishida, T. Hayakawa, M. Takenaka, and H. Hasegawa: "Directed Self-assembly with Density Mmultiplication of Cage Silsesquioxane-containing Bblock Copolymer via Controlled Solvent Annealing," J. Photopolym. Sci. Tech., Vol. 24, No. 5, pp. 577-580, 2011

22) H. Yoshida, Y. Tada, Y. Ishida, T. Hayakawa, M. Takenaka, and H. Hasegawa: SPIE, Newsroom. DOI: 10.1117/2.1201301. 004546, 2013

23) T. Iwase, M. Kurihara, Y. Hirayama, N. Negishi, T. Hayakawa, Y. Tada, and H. Yoshida: "Reducing hole-size variation and defect ratio after pattern transfer by using self-assembled polymer with spherical structure," et al., J. Vac. Sci. \& Tech., B., Vol. 31, No. 4, 041807/1-041807/9, 2013

24) R. Maeda, T. Hayakawa, and C. K. Ober: "Dual Mode Patterning of Fluorine-Containing Block Copolymers through Combined Topdown and Bottom-up Lithography," Chem. Mater., Vol. 24, No. 8, pp. 1454-1461, 2012

25) H. Takano, L. Wang, Y. Tanaka, R. Maeda, N. Kihara, Y. Seino, H. Sato, Y. Kawamonzen, K. Miyagi, S. Minegishi, T. Azuma, C. K. Ober, and T. Hayakawa: "Vertical Oriented Lamellar Formation of Fluorine- and Silicon-containing Block Copolymers without Neutral Layers," J. Photopolym. Sci. and Technol., Vol. 28, pp. 649-652, 2015

26) T. Seshimo, R. Maeda, R. Odashima, Y. Takenaka, D. Kawana, K. Ohmori, and T. Hayakawa: "Perpendicularly oriented sub10-nm block copolymer lamellae by atmospheric thermal annealing for one minute,” Sci. Rep., Vol. 6, 19481, 2016

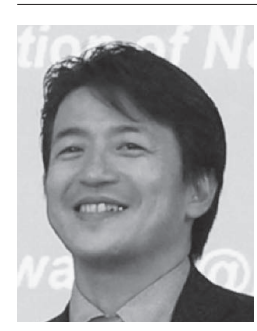

早川晃鏡（はやかわ てるあき）

著者紹介

東京工業大学物質理工学院材料系・准教授

〔経歴〕1995 年山形大学工学部卒業。2000 年同大 学院理工学研究科博士後期課程修了。同年通産省 工業技術院物質工学工業技術研究所入所。産業技 術総合研究所，東工大助手を経て 09 年より現職。 さきがけ研究者兼任。〔専門〕高分子合成，自己 組織化材料，高分子薄膜。 